\title{
Intermédialités
}

Histoire et théorie des arts, des lettres et des techniques

Intermediality

History and Theory of the Arts, Literature and Technologies

\section{Once More with Feeling: Re-investigating the Smuttynose Island Murders}

\section{Nicholas Chare}

Numéro 28-29, automne 2016, printemps 2017

refaire

redoing

URI : https://id.erudit.org/iderudit/1041079ar

DOI : https://doi.org/10.7202/1041079ar

Aller au sommaire du numéro

Éditeur(s)

Revue intermédialités (Presses de l’Université de Montréal)

ISSN

1920-3136 (numérique)

Découvrir la revue

Citer cet article

Chare, N. (2016). Once More with Feeling: Re-investigating the Smuttynose

Island Murders. Intermédialités / Intermediality, (28-29).

https://doi.org/10.7202/1041079ar
Résumé de l'article

Dans la nuit du 5 mars 1873, deux Norvégiennes ont été assassinées sur l'île de Smuttynose, dans les îles de Shoals, à deux pas de la côte du New Hampshire. Le crime a attiré et continue d'attirer beaucoup d'attention. Cet article s'intéresse à deux représentations des meurtres : un essai de Celia Thaxter datant de 1875, "A Memorable Murder », et le film The Weight of Water (Kathryn Bigelow, 2000), une adaptation du roman du même titre publié par Anita Shreve en 1997. En recourant à la pensée psychanalytique inspirée par Melanie Klein, j'analyse comment ces reconstitutions littéraire et filmique facilitent la relance du passé dans le présent. À l'aide de l'article de Ruth Riesenberg-Malcolm intitulé " Interpretation: the Past in the Present ", j'examine comment l'essai et le film favorisent une expérience analogue au transfert, tel qu'il est conçu dans la situation analytique. 


\title{
Once More, with Feeling: Re-investigating the Smuttynose Island Murders
}

\author{
Nicholas ChaRE
}

\section{INTRODUCTION: LAYING THE FOUNDATIONS}

n the night of March 5, 1873, two Norwegian women, Anethe Christensen and

Karen Christensen, were murdered on Smuttynose Island in the Isles of Shoals off the New Hampshire coast. The two women, along with Karen's sister, Maren Hontvet, had been left alone in the only inhabited house on the island. Anethe's husband Ivan (who was Karen and Maren's brother) and Maren's husband John, along with John's brother Matthew, would have usually also been in the house, but that night they were away on fishing business in nearby Portsmouth on the mainland. A Prussian, Louis Wagner, who had previously been a guest at the house but had by then moved to Portsmouth, discovered the men would be absent and rowed to Smuttynose hoping to steal John's savings. In the course of the attempted robbery, he brutally murdered Anethe and Karen, but Maren was able to escape.

The murders attracted considerable media attention at the time and were the subject of a celebrated essay- "A Memorable Murder"-published in 1875 in The Atlantic Montbly by local author Celia Thaxter, who lived on the neighbouring

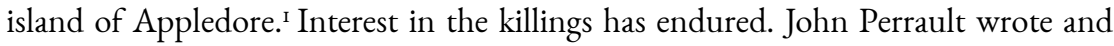
recorded the "Ballad of Louis Wagner," which featured on his 1981 album New Hampshire. ${ }^{2}$ The ballad subsequently motivated a film of the same name. ${ }^{3}$ In 1997 , Anita Shreve published a novel-The Weight of Water-which was also inspired by

ICelia Thaxter, “A Memorable Murder," The Atlantic Monthly, vol. 35, I875, p. 602-615.

${ }^{2}$ The ballad is reproduced in John Perrault, The Ballad of Lonis Wagner and Other New England Stories in Verse, Portsmouth, New Hampshire, Peter Randall, 2003, p. 3-7.

${ }^{3}$ Ballad of Louis Wagner (Gary Samson, 1985). For a brief discussion of this film, see Robert Perrault, "Petites nouvelles de la Nouvelle-Angleterre," Liaison, vol. 35, 1985, p. 16. 
the murders. ${ }^{4} \mathrm{~A}$ few years later, in 2000, a homonymous film adaptation directed by Kathryn Bigelow was released. Bigelow had read Shreve's book in manuscript form around the time of the passing of her mother, who was Norwegian, and has referred to making the film as "a kind of way to bring Mom back to life. It was very personal to me." s In this context, just like the novel, the film provides only a partial, fictionalized reconstruction of the events, which at times deviates purposefully and significantly from the historical accounts of the murders. ${ }^{6}$

To some, the artistic license displayed in the novel and the film might appear morally objectionable. In relation to traumatic events such as murder, there is a moral duty to exercise clarity and precision, to be faithful to the facts. ${ }^{7}$ Facts, as truths of events, can, however, take varied forms. Narrative fidelity to an event, for instance, does not necessarily equate to emotional fidelity. ${ }^{8}$ Focusing on Thaxter's essay and the film adaptation of The Weight of Water, I will argue that these distinct forms of testimony to the murders repeat the feelings that accompanied the violent acts they refer to. In the case of the film, this repetition at the level of feeling exists despite divergences between the narrative and the historical record. A lack of narrative veracity is compensated by a faithful and forceful communication, at a sub-narrative level, of the terror of the victims and of the killer's murderous affects. ${ }^{9}$ A film that got the story "right," that told things as they actually happened, might simultaneously fail to adequately or appropriately register these affects. By deliberately choosing a

${ }^{4}$ Anita Shreve, The Weight of Water, London, Little, Brown and Company, 1997.

s Peter Howell, "Direct from the Gut," in Peter Keough (ed.), Kathryn Bigelow Interviews, Jackson, Mississippi, University Press of Mississippi, 2013, p. II8.

${ }^{6}$ For historical accounts of the murders, see David Faxon, Cold Water Crossing: An Account of the Murders at the Isles of Shoals, CreateSpace Independent Publishing Platform, 2009; Edmund Pearson, Murder at Smutty Nose and Other Murders, New York, Doubleday, I926; J. Dennis Robinson, Mystery on the Isles of Shoals, New York, Skyhorse, 2014; Lyman Rutledge, Moonlight Murder at Smuttynose, Boston, Starr King Press, 1958; Emeric Spooner, Return to Smuttynose Island and other Maine Axe Murders, CreateSpace Independent Publishing Platform, 2009.

7 See, for example, Hayden White's analysis of Primo Levi's meditations on how to write appropriate Holocaust testimony in White, "Figural Realism in Witness Literature," parallax, vol. IO, no. I, 2004, p. II3-I24.

${ }^{8}$ See the discussion of Dori Laub's understanding of fact in relation to emotion in Nicholas Chare and Dominic Williams, "Questions of Filiation: From the Scrolls of Auschwitz to Son of Saul," Mémoires en jeu, no. 2, 2016, p. 65-67.

9 For a discussion of murderous affects, destructive impulses that, when acted upon, can cause a person to commit murder, see Mara Sidoli, "Hearing the Roar," Journal of Analytical Psychology, no. 43, 1998, p. 23-33. 
film that provides a narrative fiction of the murders yet offers a faithful attestation to the feelings that underpinned them, I am able to highlight this. We know of the feelings that accompanied the murders through $\operatorname{court}^{\mathrm{IO}}$ transcripts relating to the trial of Louis Wagner, particularly the testimony of Maren Hontvet, which provide evidence of the emotions (the fear of the victims, the killer's murderous rage) experienced that fateful night. Information gathered regarding the dynamics of the crime scene also give reliable insights into Wagner's criminal personality.

Thaxter's essay is considered, in conjunction with the film, as a means to trace how a constant affective memory of the murders carries across time and through different media. Both the film and Thaxter's essay, which is highly literary and impressionistic, provide a way of conceiving the recording of history that differs from the conventional view of it as a narrative-making endeavour. ${ }^{\text {II }}$ The two texts exploit their sub-narrative aspects to express the feelings that accompanied and underpinned the historical events they depict. These feelings of fear and rage may differ in their intensity from the feelings that accompanied the actual murders. The feelings are staged, re-enacted. As affects, however, they are palpable, permitting a touching, terrifying encounter with the past. To use Rebecca Schneider's terms, they form "a complex crosshatch" of past and present, an "affective assemblage." ${ }^{12}$ Joan Scott's observations on the distinct temporalities of psychoanalysis and traditional historicizing help to make sense of this crosshatch. Scott emphasizes that for the psychoanalyst "the objective times of past and present are confused, often indistinguishable," with time recognized as "a complex creation, a constructed dimension of subjectivity, not a chronological given.” ${ }^{\text {13 }}$ For her, psychoanalytic transference, for example, "necessarily disrupts the temporal order of conventional history." ${ }^{14}$ Scott and Schneider, in their different ways, both work to undo conceptions of history as a linear narrative, troubling the idea of the past as irrevocably other to the present.

ro "Supreme Judicial Court of Maine. The State v. Louis H. F. Wagner," The American Law Register (I852-I89I), vol. 22, no. 2, 1874, p. I06-I20, http://www.jstor.org/stable/3303455 (accessed October 9, 2017).

II See, for example, Alun Munslow, Narrative and History, Houndmills, UK, Palgrave, 2007.

${ }^{12}$ See Rebecca Schneider, Performing Remains: Art and War in Times of Theatrical Reenactment, London, Routledge, 20II, p. 35.

${ }^{13}$ See Joan W. Scott, "The Incommensurability of Psychoanalysis and History," History and Theory, no. 51, 20I2, p. 67.

${ }_{14}$ Ibid., p. 79. 
Robert Rosenstone suggests that film as history "should not and cannot be judged by the criteria we apply to the history that is produced on the page." Is For him, film has the capacity to help "create in us the feeling that we are not just viewing history, but actually living through events in the past, experiencing [...] what others felt $[. ..] .{ }^{\text {}}{ }^{6}$ By drawing on post-Kleinian psychoanalytic theory, I will examine how essay and film permit this kind of emotional reliving to occur. The histories as the feelings that they bring out do not conform to traditional visions of history as a domain of hard facts. ${ }^{17}$ They celebrate a softer, rigorously sentimental kind of historiography. The kinds of history they incarnate (highly attentive to the affective) resist what Rebecca Schneider refers to as "Great Man history," history claiming to be objective and banishing emotion as subjective. ${ }^{18}$ The film and essay that I analyse can, therefore, be understood to embody a practice of feminist historiography which preserves the affective, and performatively works against the privileging of material remains, against the fetishizing of the archival hard stuff over histories of feelings. Schneider celebrates histories articulated through feelings, particularly theatrical histories. Like these theatrical histories, the film and the essay also provide reenactments of past events. They can equally be understood as constituting works of feminist history.

In the context of feminism, The Weight of Water is also noteworthy for how it contributes to a broader feminist project associated with Bigelow's work, one that links many of her earlier films. Drawing on Bracha Ettinger's psychoanalytic theories, I have previously traced how Blue Steel (Bigelow, 1989) and Point Break (Bigelow, I99I), for instance, gesture towards a form of feminist cinema that is not bound to the castration paradigm and the phallic economy. ${ }^{19}$ Understanding such cinema requires rethinking the relationship between psychoanalysis and film in a way that is not wholly Lacanian in impetus. Turning to Melanie Klein and to post-Kleinian psychoanalytic theory opens alternatives to film analyses, such as, most notably, those

is Robert A. Rosenstone, History on Film/Film on History, $2^{\text {nd }}$ ed., Harlow, UK, Pearson, 2012 , p. 42.

${ }^{16}$ Ibid. p. 45.

${ }^{17}$ See Schneider's discussion of hard versus soft historicizing in Schneider, Performing Remains, p. 14.

${ }^{18}$ Ibid., p. 75 .

19 See Nicholas Chare, "Encountering Blue Steel," in Griselda Pollock (ed.), Visual Politics of Psychoanalysis, London, IB Tauris, 2013, p. 190-207; Nicholas Chare, Sportswomen in Cinema, London, IB Tauris, 2015, p. 157-182. 
of Christian Metz and Laura Mulvey, that are predominantly inspired and underpinned by the ideas of Jacques Lacan. ${ }^{20}$

For Lacan, there are three registers of psychic reality: the Real, the Imaginary, and the Symbolic. Acceding to the Symbolic requires the cut of difference that is entry into language. This cut traumatically severs the subject from the Real, the realm of maternal plenitude. Once the child begins to use symbols, objects lose their importance. ${ }^{2 \mathrm{I}}$ In such a conception of psychic development, Kleinian-inspired object relations theory can only assume a secondary importance. Symbols (signifiers such as words) become the things that matter. Turning to Klein and her successors, however, enables us to account for phenomena in The Weight of $W$ ater that manifest in excess of the signifier. These sub-narrative phenomena, emerging at the edges of the Symbolic Order, preserve traces of early infantile psychic life, of elemental conflicts, in the present. They coax felt memories of the Real, of the pre-oedipal, to the fore in the spectator. If these feelings are apprehended rather than ignored, then the anxiety and aggression caused by the trauma of separation from the Real might be mitigated. ${ }^{22}$ The feelings embody continuity, the conservation of early mother-child relations, of a psychic past, in the present. The way these feelings are realized in the cinematic experience bears similarities with transference as it emerges in the relationship between analysand and analyst in psychoanalysis.

\section{ENCOUNTERING TRANSFERENCE}

Sigmund Freud described transference as embodying "new editions [Nenauflagen] or facsimiles [Nachbildungen] of the impulses and phantasies which are aroused and made conscious during the progress of [an] analysis." ${ }_{23}$ Transference for Freud was therefore a process of replication, of publication of hitherto

${ }^{20}$ Metz does occasionally acknowledge Klein's ideas in The Imaginary Signifier but his overarching conception of cinema remains Lacanian. See Christian Metz, The Imaginary Signifier: Psychoanalysis and the Cinema, Bloomington, Indiana, Indiana University Press, 1982. Klein's thinking has also been linked to cinema by, among others, Jean-Louis Baudry who makes brief yet tantalising references to her ideas. See Baudry, L'effet cinema, Paris, L'Éditions Albatros, 1978, p. 45; p. 46, note I. Jackie Stacey also discusses the potential of object relations theory for film analysis and highlights the dearth of Kleinian-inspired thinking about film. See Stacey, Star Gazing, London, Routledge, 1994, p. 227-230.

2I Jacques Lacan, Freud's Papers on Technique, 1953-1954, New York, W. W. Norton \& Co., I991, p. 178.

${ }^{22}$ Chare, 2013, p. 202-207.

${ }_{23}$ Sigmund Freud, "Fragments of an Analysis of a Case of Hysteria ('Dora')" [1905], The Penguin Freud Library, vol. 8, London, Penguin, 1990, p. 157. 
unconscious material. This replication may result in an identical copy (which differs only from the original in its status as substitute) or a modified copy. Freud referred to the modified copy as a "revised edition" [Neubearbeitungen], a dissembling version of the originating material. The kinds of feelings and phantasies that register in the film and the essay have not undergone this kind of modification. As reenactments of the murders, they differ from it only in their quality as substitution. The metaphor of republication, of reissuing, makes clear that this substitution is not qualitatively different but rather temporally distinct from the former manifestations of feeling. This temporal distinction is, however, of a complex kind. Freud explains that in the transference "a whole series of psychological experiences are revived, not as belonging to the past, but as applying to the person of the physician at the present moment." ${ }^{24}$ Klein correspondingly refers to the transference as a means of reviving the past, reawakening it in the present. ${ }^{25}$ The bringing into question of the singularity of present and past through transference will subsequently be examined in more depth.

Metz rightly suggests that real transference is impossible in cinema (his remarks could also be extended to literature). ${ }^{26}$ Jean Deprun similarly acknowledges marked differences between transference in analysis (emerging in a caring yet austere setting) and cinema (comprising a less sober setting). ${ }^{27}$ For Deprun, however, processes of identification as they occur in viewing films do share characteristics with transference. Elizabeth Cowie provides a sophisticated exploration of how the dynamics of transference can be linked to processes of identification in cinema. Cowie perceives cinema as comparable to transference through its capacity to construct "a scenario where typical and universal projections are played out to which we relate as if they were our own. ${ }^{28}$ Films assume a role akin to that of the analyst, containing the spectator's feelings, lending form and expression to them.

As Cowie explains, identification by the spectator is often with the narrative. ${ }^{29}$ I want to additionally explore how sub-narrative aspects contribute to identificatory processes. These aspects-rhythmic, chromatic, gestural-enable the spectator (or reader) to realize certain feelings. Films such as The Weight of Water hold these

${ }^{24}$ Freud, 1990, p. 157-58.

${ }^{25}$ Melanie Klein, "The Origins of Transference" [1952], in Klein, Envy and Gratitude and Other Works, London, Vintage, 1997, p. 48.

${ }^{26}$ Metz, 1982, p. 34.

${ }^{27}$ Jean Deprun, "Cinéma et transfert," Revue internationale de filmologie, no. 2, 1947, p. 207.

${ }^{28}$ Elizabeth Cowie, Representing the Woman: Cinema and Psychoanalysis, Minneapolis, University of Minnesota Press, 1997, p. II3.

${ }_{29}$ Ibid., p. II7. 
feelings for the spectator yet also return them to the spectator through a process comparable to interpretation. This enables the spectators to recognize and learn from the mechanism of transference, to come to know and understand their feelings. These powerful feelings of love and hate, which form the subject's emotional bedrock, were initially encountered in infantile phantasies, early object relations, and are revived via the cinematic experience.

Drawing predominantly on Ruth Riesenberg-Malcolm's consideration of the analytic situation, I explore how the Smuttynose murders can be understood alternatively either as an event that is over and done with and split off from the present or as something persisting, living on affectively in the present..$^{30}$ RiesenbergMalcolm provides an exceptionally nuanced and sensitive understanding of temporality in relation to transference. She suggests there are two kinds of past at work in the analytic situation: the inferred historical past and the alive past. ${ }^{31}$ The inferred historical past refers to what must have taken place even if it cannot be remembered. It is archaic mental history that is inaccessible to recall. The alive past comprises aspects of the past as they manifest in the present through the process of transference. It is this alive past that I want to consider as a form of re-enactment. In the next section, I lay out the psychoanalytic framework that informs my understanding of re-enactment as it is embodied in the representation of the murders.

\section{The Past in the Present}

Riesenberg-Malcolm explains that during analysis "the patient communicates his psychic world to the analyst by experiencing it and reliving it in the transference." ${ }_{2}$ Transference, the analysand's relationship to their analyst, can therefore be understood as a kind of reactivating of early psychic life, a repetition of past object relations, of primary internal and external relationships. It can assume the form of an acting out, a reliving in the present of past distressing experiences, a compulsive repeating of them. Betty Joseph advises that in analysis understanding of the transference derives from attending to how patients "unconsciously act out with [the analyst] in the transference." 33 Repressed material is revived through the

30 Ruth Riesenberg-Malcolm, On Bearing Unbearable States of Mind, London, Routledge, 1999.

${ }^{31}$ Ibid., p. 4I.

${ }^{32}$ Ibid., p. 38.

33 Betty Joseph, Psychic Equilibrium and Psychic Change, London, Routledge, 1989, p. I57. 
relationship with the analyst via the transference. For analysis to be effective, acting out must be supplemented with working through. ${ }^{34}$ Working through proceeds through encouraging patients to interpret their situation and gain insight into it thereby freeing themselves as much as possible from the compulsion to repeat. Drawing on Riesenberg-Malcolm's ideas, the psychiatrist Ronald Doctor observes of his work with patients who have committed violent crimes that what causes the past to become alive in the present through the transference is the bringing to the fore of events "that lie hidden in the shadows." 35 By means of discovering these events, patients can come to understand themselves, tolerate their emotions, and build a new autobiography. Re-enactment as embodied in acting out therefore facilitates working through by way of the interpretations it can help to generate.

It is through an analysis of transference that the analyst forms interpretations. These include a consideration of his or her own responses to the analysand's transference, responses referred to as counter-transference. An interpretation is therefore, properly speaking, formulated via a construction derived from both transference and counter-transference. The transference emerges in the here and now of the analytic situation but it is composed of what Riesenberg-Malcolm terms "an alloy of past and present." ${ }_{36}^{6}$ It is an intimate mixture of the now and the then because "the analyst understands the patient's present relationship to him as a function of the past. Therefore his understanding of the present is the understanding of the patient's past as alive and actual now, in the present." 37

This sense of a past as alive in the present is central to a psychoanalytic understanding of the essay and of the film that take the Smuttynose murders as their subject and re-enact it. The alive past is constituted from what Klein refers to as "memories in feelings," memories related to the drives. ${ }^{8}{ }^{8}$ In psychoanalysis the drives operate as representatives of the body in thought, mediating between the somatic and the psychic. Childhood memory without feeling, pared of any drive-investment, is

${ }^{34}$ See Michael Feldman's discussion of Betty Joseph's work in relation to repeating and working through in Feldman, Doubt, Conviction and the Analytic Process, London, Routledge, 2009, p. 80-8I.

35 Ronald Doctor, "The History of Murder," in Ronald Doctor (ed.), Murder: A Psychotherapeutic Investigation, London, Karnac, 2008, p. 82.

36 Riesenberg-Malcolm, "Interpretation: The Past in the Present," in RiesenbergMalcolm, 1999, p. 52.

37 Ibid., p. 40.

${ }^{38}$ Melanie Klein, "Envy and Gratitude” [1957], in Klein, 1997, p. I80. 
anecdotal. 39 It is the detached narration of an interesting event pared of any emotional tenor. Memories in feelings, by contrast, are resistant to narration as they are associated with the pre-verbal. In her 1957 essay "Envy and Gratitude," Klein elucidates memories in feelings as composed of "pre-verbal emotions and phantasies." 40 These memories register as cadence or intonation or manifest through an analysand's comportment and gesture.

$I_{15} \quad$ Hans Loewald usefully distinguishes between dramatization and narrative, or re-enactment and historical account, in the psychoanalytic situation. For Loewald narration is characterized by detachment from past actions, while dramatization involves proximity to them. The dividing line between these two forms or modes of remembering is not "sharply drawn" and Loewald observes that "the patient who describes an experience with a great deal of affect is more identified with that experience, is less objective about it; the past invades the present." ${ }^{4 \mathrm{I}}$ Memories in feelings can be equated with affect as it is discussed here. Their presence signals that re-enactment rather than straightforward narration is at work and that the past is in the present, encroaching upon it. This is what occurs in the essay and the film.

In both the film and the essay, affect or memories in feelings, as reenactments, register through the uses of colour, gesture, rhythm, and sound. This aesthetic dimension permits particular feelings of the audience members to resonate with what is portrayed in words or on screen, to be realized and, ultimately, to be recognized. Moments occur where narrative cedes to drama and the reader or spectator is encouraged to identify with the psychic processes of the characters, to contain what seem to be their feelings, feelings that for the spectators and the readers actually derive from closer to home. These feelings, which ostensibly come from without, actually form the reader's or the spectator's own memories, memories that are relayed back to them through the time of their encounter with the essay or the film.

A good analyst is accustomed to the presence of memories in feelings as they are signalled through the analysand's demeanour and speech and is attuned to the way that they surface through projective identification. Projective identification in the analytic situation comprises a defence mechanism used by patients to protect against unbearable mental contents. ${ }^{42}$ For a variety of reasons, the patient will seek to

39 Riesenberg-Malcolm, “Construction as Reliving History,” in Riesenberg-Malcolm, I999, p. 77.

40 Klein, "Envy and Gratitude" [1957], 1997, p. I80, note I.

${ }^{41}$ Hans Loewald, Papers on Psychoanalysis, New Haven, Connecticut, Yale University Press, 1980, p. 365.

${ }^{42}$ Feldman, 2009, p. 23. 
insert or project threatening parts of him or herself onto the analyst. This action contains non-verbal communicative elements. Riesenberg-Malcolm writes that these "are elements that often cannot be expressed in any other way, perhaps because the experiences and phantasies involved occurred before language had been established, or perhaps because the projection refers to nameless feelings, or perhaps because it repeats a very early infantile experience." 43 It is extremely important to attend to these messages that, as feelings, are communicated through tone and gesture. Access to this emotional history is accomplished through containing the patient.

Riesenberg-Malcolm turns to Wilfred Bion's research on “reverie” to explain how this containment occurs in the analytic situation. Reverie, the mother's acceptance and transformation of a child's bad feelings, forms a vital part of the container/contained relationship that is established in early infancy. ${ }^{44}$ Bion argues that the precursor to memory can be found in this relationship. Infants are initially overwhelmed with raw sense data (what Bion termed "beta-elements") which they do not possess the psychic capacity to process. They thus feel compelled to expel this data. It is usually pushed out, projected onto the breast, the prototypical object that the infant relates to. As Hanna Segal explains, these "unorganised, inchoate elements of experience [...] undergo a transformation into alpha-elements" by way of the maternal breast. ${ }^{45}$ Alpha-elements give form to raw experience: shape it into an image or feeling, a word, the precursors of thought, which the elements will eventually evolve into. The mother's role in this interaction is, as Segal clarifies, to offer "the word or phrase which binds this experience." ${ }^{6} 6$ Through containing, encompassing, and expressing the meaning she "provides a container for it." 47 The mother takes in the infant's raw experiences and then, through reverie, returns these experiences to the child in a bearable, contained form. Eventually, the child will itself internalize this capacity to contain. ${ }^{48}$

Through projective identification in the transference, the analyst similarly receives inchoate, wordless experiences, memories in feelings, which must be

43 Riesenberg-Malcolm, "Interpretation: The Past in the Present," 1999, p. 40.

44 Wilfred Bion, Learning from Experience, London, Heinemann, 1962.

45 Hanna Segal, Yesterday, Today and Tomorrow, London, Routledge, 2007, p. 86.

${ }^{46}$ Hanna Segal, The Work of Hanna Segal: A Kleinian Approach to Clinical Practice, London, Free Association Books, 1986, p. 63.

47 Ibid.

${ }^{48}$ If the mother fails to perform this role, or the infant will not permit the mother to, then emotional life may subsequently become intolerable. Doctor suggests that "it is a short step from hatred of the emotions to hatred of life itself, and ultimately to murder.” See Doctor, 2008, p. 80. 
transformed, given linguistic expression, in the interpretation. The analyst differs from the mother in that "the analyst always requires a conscious perception and further elaboration of what he has sensed: only then can he understand it as a communication." ${ }^{49}$ An analyst who consciously only listened to words, whose ear was not attuned to the feelings that accompanied them, who had no capacity for countertransference, would not recognize these archaic, emotional communications. This would not mean the feelings had not been transferred, only that they had not been elaborated. "A Memorable Murder" and The Weight of Water engage in comparable practices of elaboration. They hold the reader's or the spectator's feelings, loan form to them, and, through the scaffolding that is their narrative dimension, provide something analogous to an interpretation. I will now examine the different ways in which the film and the essay permit the revival of memories in feelings and their containment.

\section{RECONSTRUCTION AND INTERPRETATION}

The island that plays the part of Smuttynose in the film The Weight of Water is not Smuttynose Island in the Isles of Shoals. For the film, Smuttynose was "relocated" northwards up the Gulf of Maine to Nova Scotia, Canada. The Smuttynose seen on screen is a composite of locations in East Dover, West Dover, and Taylor Island (also known as Dover Island). It was on Taylor Island that a replica of the Hontvet house or Red House was built. The replica was dismantled once filming was finished. The original Hontvet house, which was pillaged for bloodstained wood and wallpaper by souvenir hunters after the murders, burned down in I885..$^{\circ}$ Now it is a ruin, only the stones that formed its foundations remain. A reconstruction of these foundations also features in the film.

The Weight of Water includes scenes set in the nineteenth century that show the Hontvet house as a place lived in, containing décor and household goods of the time. Its inhabitants are represented wearing period dress. Considerable effort is therefore made to faithfully depict the historical setting in which the murders took place. This effort can be interpreted as a familiar kind of reconstruction in historical or period films, one aiming to openly presence the past. The mise-en-scène-the set, the props, the costumes-contributes to a kind of historical re-enactment, providing a period feel to those sequences that are explicitly set in the nineteenth century. The

49 Riesenberg-Malcolm, “Construction as Reliving History,” 1999, p. 73

so For discussions of the actions of souvenir hunters, see Robinson, 20I4, p. I6o; p. 264 ; p. 298. 
re-enactment of interest here, however, is not one that is equivalent to, or reliant upon, this kind of trompe-l'ail approach to the past. It is a re-enactment that registers foremost through being attuned to the communication of memories in feelings. The character of the photographer Jean Janes (played by Catherine McCormack), whose ability to admit memories in feelings is not linked to the film's nineteenth-century mise-en-scène, best embodies this kind of re-enactment.

The plot of the film adaptation of The Weight of Water revolves around Jean who is investigating the double murder in the present. She is accompanied on a research trip to the Shoals by her husband Thomas (Sean Penn), his brother Rich (Josh Lucas), and his brother's girlfriend Adaline (Elizabeth Hurley). Jean gradually discovers that the life of the sole survivor of the murders, Maren (Sarah Polley), mirrors her own in that both experience an unhappy marriage. The two women are also united in their envy of others. The Weight of $W$ ater differs from the actual event of the murders in that it ultimately suggests the violent crime was perpetrated by Maren because of her jealousy of Anethe's marriage to Ivan. In both film and novel it is suggested that Maren had an incestuous relationship with Ivan in Norway before her marriage and emigration to America. There is no archival evidence to support this interpretation or the suggestion that her marriage was unhappy, or the idea that she committed the murders. The testimony presented against Wagner at his trial was compelling. The reconstruction of events given in the film and the novel is therefore, at a narrative level, a rewriting of history.

Reconstruction is an overt theme in The Weight of $W$ ater. There is an early scene, for example, in which Jean is shown visiting Smuttynose to study the ruins of the house where the murders took place. Writing of film portrayals of ruins, André Habib describes how architectural remains can sometimes act as archives providing a means by which the past reappears in the present.$^{5 \mathrm{I}}$ Such a re-emergence occurs as Jean studies the vestiges of the house, surveying the remaining foundations, and then reconstructing the placement of the rooms and of the bodies found within them. As she scans the enduring stonework, she voices her thoughts on the positions of the corpses whilst looking towards where she believes they would have been situated: "Yeah, about over there and... here." Jean is engaging in something akin to crime scene reconstruction, seeking to determine what events took place and their sequence through documenting and analyzing the scene of the murders.

${ }^{51}$ André Habib, L'attrait de la ruine, Crisnée, Belgium, Éditions Yellow Now, 20II, p. 63 
Simultaneously with Jean's mental placement of the corpses, the film shifts briefly from the present to the past including black and white shots of the bodies in their respective locations. In these instants, it is as if Jean is looking beyond the present into the past. The monochrome images serve to remind the audience that what they are seeing is not in the here and now. They date the seen. There are, however, also colour shots of the past prior to and after these black and white shots. This differentiation, this double-vision of the past, appears to have been motivated by a desire to depict Jean as still emotionally outside the events that took place on March 5, I873. The black and white shots enact a distancing, signal an objectivity on Jean's part. Colour, by contrast, incarnates the presence of memories in feelings. In "Giotto's Joy," Julia Kristeva suggests chromatic experience partly involves the registration of elements that exceed signification, excitations that potentially manifest as intense feeling. ${ }^{22}$ Through the oscillating absence and presence of colour, The Weight of $W$ ater proffers and denies feelings, using colour as a way to contrast differing ways of approaching and interpreting the past.

Jean's opening reconstruction of the past, performed within the building where the events took place, is dispassionate. She is reconstructing but not reliving the past. In her conscious thinking, the past is not alive to her. The black and white footage captures her self-perception of her relationship to the material she is investigating, her perceived objectivity regarding the murders. The scene as a whole, however, reveals that the boundary between past and present, which Jean perceives to be secure, is, in fact, potentially permeable. There are clear cuts between the images, between colour shots of Smuttynose now and the black and white and colour shots of how it appeared in 1873 . The porosity between past and present is rendered acoustically. In the first instance this occurs by way of a shot of Maren shouting for help. This shot is followed by one of Jean in the present. The sound of the shout carries across the two shots. It startles Jean causing her to look in the direction of the noise (see Fig. I). In this moment, she turns towards the past, hears it.

$5^{2}$ Julia Kristeva, "Giotto's Joy," in Desire in Language: A Semiotic Approach to Art and Literature, Oxford, Blackwell, 1981, p. 210-236. Kristeva's thinking is usually regarded as extending Lacan's, yet it actually attempts a complex reconciliation of Kleinian and Lacanian ideas. For a nuanced exploration of this endeavour, see Mary Jacobus, “Tea Daddy': Poor Mrs Klein and the Pencil Shavings," in Jacobus, First Things: The Maternal Imaginary in Literature, Art and Psychoanalysis, New York, Routledge, 1995, p. I29-I52. 


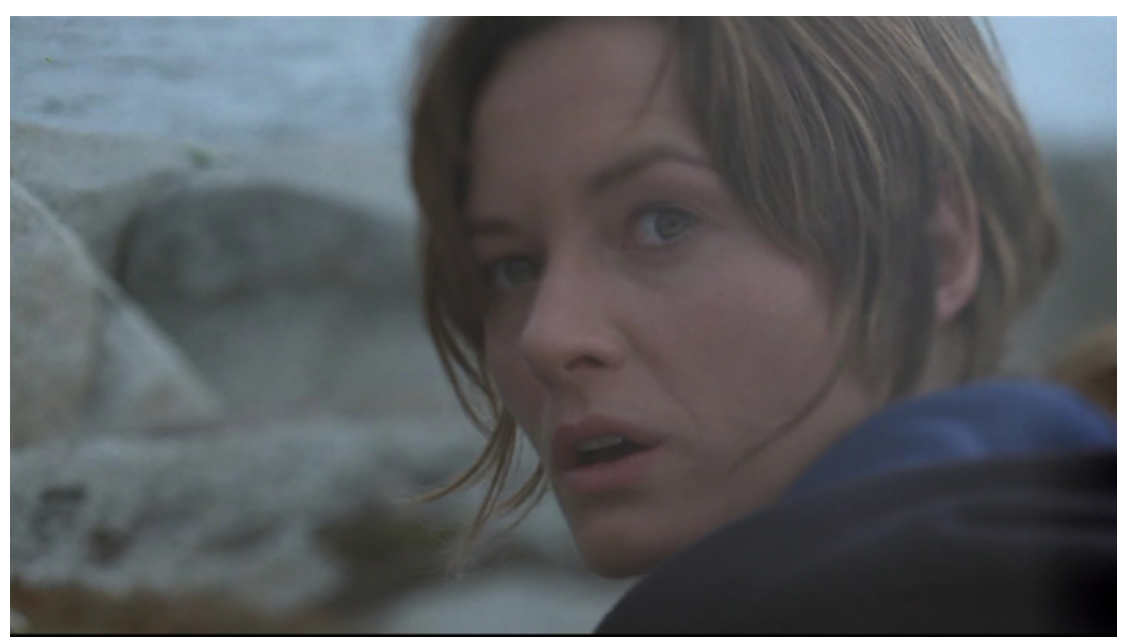

Fig. I. Still from the film The Weight of Water, Kathryn Bigelow, Momentum Pictures, 2000. Hearing the past in the present.

It is noteworthy that none of Jean's companions on the island register this shout. It is only she who perceives it. The heightened listening skills of the photographer in this scene are not incidental. The employment of the sound bridge shows that Jean is the only character willing to listen to the past as a locus of feelings, to lay herself open to it. This listening takes the form of a heightened attentiveness to material and written testimonies, it encompasses a kind of close reading of the emotional significance contained in both words and things that are linked to the murders. Jean's companions appear too distracted or disinterested to emulate her emotive insights. This attentive attitude towards the murders is comparable to the clinical act of listening in that it enables Jean to register memories in feelings. Like Jean, the film's viewers must be similarly attentive to the feelings it communicates, to its sub-narrative dimensions, if they are to participate in re-enacting the past in the present. Through its visual parallels, its rhymes and rhythms, The Weight of Water provides materials to enable such a re-enactment.

\section{All at SeA}

An example of the way the film employs graphic matches to unite the past and the present occurs when Jean seeks out the boulder beneath which Maren sheltered for the remainder of the night after fleeing the scene of the murders. Again, Jean initially engages in reconstruction with the black and white shots of the rocks signalling her thought processes as she tracks the route she believes Maren must have 
taken to the boulder. Jean removes her shoes in a seeming effort to step barefoot into Maren's shoes, to feel as Maren felt that night, to become her. The monochrome shots of the nineteenth century are soon replaced by colour ones as the film cuts back and forth between shots of Jean and of Maren both making their way towards the rock and then crouching beneath it (see Fig. 2-3).53 Through the use of cuts, the women are shown as temporally discrete yet as engaging in similar physical actions and as linked by sound bridges - the sound of the sea and of a child singing a Norwegian folksong unify the sequence. 54 In this way, as Deborah Jermyn has recognized, "the dual narrative sometimes disrupts the conventions of filmic time and space." 55 There is again a gestural and acoustic link formed between the present and the past. ${ }^{56}$
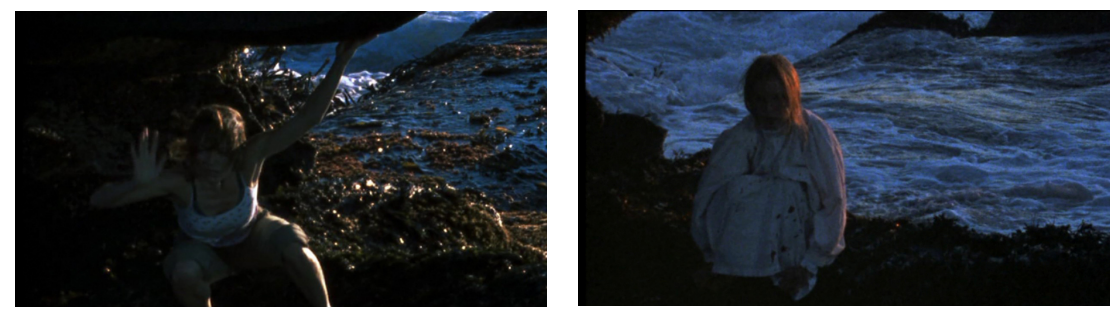

Fig. 2-3. Still from the film The Weight of Water, Kathryn Bigelow, Momentum Pictures, 2000. Example of a graphic match, in which we see the characters of Jean and Maren beneath the boulder.

53 There is later a black and white shot of Maren crouching beneath the boulder. This occurs as she is giving testimony against Wagner at his trial. Since her account of the murders, as portrayed in the film, is made up rather than remembered, the monochrome images might signal her lack of emotional investment in what she is saying.

54 The folksong is an oblique reference to Thaxter's "A Memorable Murder," which describes Karen Christensen as "crooning sweet, sad old Norwegian airs" (p. 604). It also may be an allusion to Thaxter's poem "Karen" which refers to a "sorrowful, sweet Norwegian song" that the author wishes to "unravel and understand" but cannot. See Thaxter, The Poems, Boston, Houghton Mifflin, I9I4, p. II8.

s5 Deborah Jermyn, "Cherchez la femme: The Weight of Water and the search for Bigelow in 'a Bigelow film'," in Deborah Jermyn and Sean Redmond (eds.), The Cinema of Kathryn Bigelow, London, Wallflower Press, 2003, p. 130-I3I.

${ }_{56}$ The composer of the score for The Weight of Water, David Hirschfelder, discusses more general conscious efforts to link the two time frames of the film through, for instance, employing a tenor saxophone in scenes set in the nineteenth century. See John Davey, "A Foot in Both Worlds," Metro, nos. I29-I30, 200I, p. 230. 
The film exploits the use of similar gestures, actions and events, the use of graphic matches across shots, to build a visual poetics, rendering The Weight of Water rhythmically complex. Gestural matching is present from early on. In the beginning of the film, John, for instance, is shown compassionately placing his hand on Ivan's back as Ivan is confronted by Anethe's corpse. Shortly afterwards, in the present day, Thomas and Rich pat each other on the back in a show of affection. There are also events that can be said to rhyme with each other. Thomas knocks Jean's glass of red wine onto the wooden deck of the yacht, where it smashes, leaving a red pool and shards of glass. Shortly afterwards, Jean dreams of a clock on the mantelpiece in the Red House falling to the ground and its face shattering. 57 Upon waking from this dream, she has become convinced that Wagner is not the murderer. The clock face breaking is shown once again when Maren is depicted committing the murders. Maren's murderous rage is triggered by her sister walking in upon Maren and Anethe as they sleep, mistaking their being together as evidence of lesbianism, of "sinfulness," and then revealing to Anethe the act of incest between Maren and Ivan that had precipitated Maren's leaving Norway. It is clear from a flashback that it was also Karen who discovered Maren in bed with Ivan. Here Karen re-enacts this moment of discovery with fatal consequences.

Another graphic match occurs between a scene of Jean doing research into the murders at an archive in Portsmouth, where a wall fan can be seen rotating in the background, and the following shot in which Karen is shown in the Red House spinning at a wheel by the fireplace, the fire casting a flickering light against the creamcoloured side-liner ${ }^{8}$ (see Fig. 4-5). Visible correspondences such as this comprise the filmic equivalent of rhymes, of words that sound the same. The shot of the spinning wheel is also an example of intertextuality, a visual allusion to Thaxter's poem "Karen" about Karen Hontvet who:

At her low quaint wheel $[\ldots]$ sits to spin,

Deftly drawing the long, light rolls

Of carded wool through her fingers thin,

By the fireside at the Isles of Shoals. 59

$57 \mathrm{~A}$ wall clock above the bed Karen was sleeping in was knocked to the floor during the actual murders. See Robinson, 20I4, p. 9I.

$5^{8}$ Bigelow also includes shots that feature lens flare and a lens partially obscured by sea spray-visual disturbances that are consonant with each other.

59 Thaxter, 1914, p. II7-II9. 

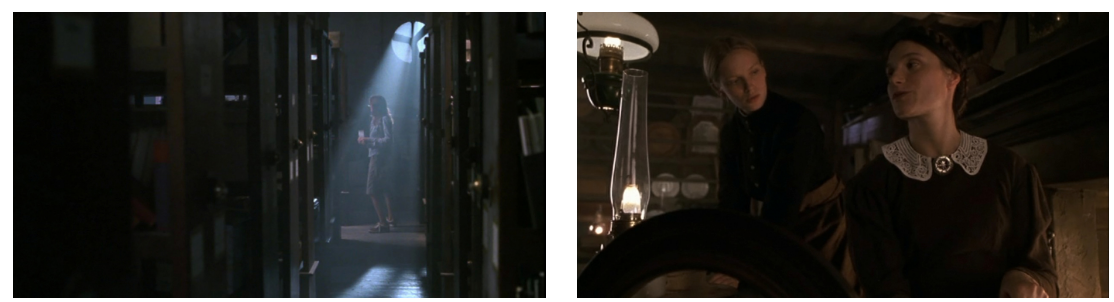

Fig. 4-5. Still from the film The Weight of Water, Kathryn Bigelow, Momentum Pictures, 200o. Parallels across time: the wall fan in the archive and the spinning wheel in the Hontvet house.

Through its use of imagery, Thaxter's poem lends itself well to being referenced in the film. In addition to intertextual references such as this, The Weight of Water uses the repetition of similar gestures, lighting, motions, and shapes to provide a poetic dimension. It is far from unique in its use of graphic matches, but Bigelow brings visual poetics to the fore exceptionally thoughtfully, using visual consonances to create crossover between scenes set in the nineteenth century and the present, encouraging the spectator to contemplate the presence of the past in the present.

The way memories in feelings from the nineteenth century carry to the present is also communicated through what might best be referred to as "emotional rhyming." The actors playing Jean (Catherine McCormack) and Maren (Sarah Polley) both deliver sophisticated performances suggesting frigidity, jealousy, tension, and suppressed rage. These emotional states are seldom verbalized but are communicated through bodily comportment, facial expression, and actions. Additionally, the women occasionally display tenderness, rare yet more noteworthy because of that, such as Maren kissing Anethe and Jean photographing Thomas and Rich while they caper on the deck of the yacht and then Rich as he undresses to go swimming. ${ }^{60}$

The contrasting emotions of love and hate, anger and joy, embodied at differing times by the women are likewise reflected in the behaviour of another character, the sea. In its sound and motion, its aggression and confusion, the sea forms a major way in which memories in feelings are solicited. During the scene of Jean retracing Maren's steps, for example, whilst the photographer is sheltering beneath the rock in the same pose as Maren, she is struck by an inrush of water causing her to cry out. This upsurge does not contribute to the film's narrative yet it is not without

6o It is notable that when Jean looks through the lens, she is portrayed as seeing in black and white, as if the camera provides her with an unfeeling, objective perspective on things. 
significance. Similarly, one shot of Maren beneath the rock in this sequence shows her framed by a backdrop of seething sea. The rock is invisible. The sea here enacts Maren's anger and re-enacts it in the present when it strikes Jean. It should not, however, be understood simply as visual metaphor or pathetic fallacy. For the spectator, it is also an overture to affect.

The sea embodies distress and fear throughout The Weight of Water (and in Thaxter's essay). Towards the end of the film, the depiction of the sea is clearly split, possessing two differing characters. There is a sequence in which the yacht, which has brought Jean and her companions to the island, is caught in a storm. The efforts to keep the boat afloat in the rough seas are intercut with shots of Maren committing the murders and of the trial that took place in their aftermath. In the present, Jean, who has recently realized that her husband has been having an affair with Adaline, uses the yacht's boom to knock Adaline into the sea. This occurs at the same moment that Maren attacks her sister with a chair, smashing it against her. In the present, Thomas dives into the sea in an effort to save Adaline. This causes Jean to also leap into the deep in what appears to be a suicide attempt.

During the storm the sea's surface is shown to boil, crash, seethe, engulf. Beneath, however, the sea is depicted as calm, placid, quiet. After Jean jumps into the sea and sinks under the waves, she encounters Anethe and Maren in the gentle waters. Jean literally grasps Anethe's hair (see Fig. 6). Here the past is shown to be in the present. This scene forms a final collapsing together of what have otherwise been discrete, if permeable, visual universes.

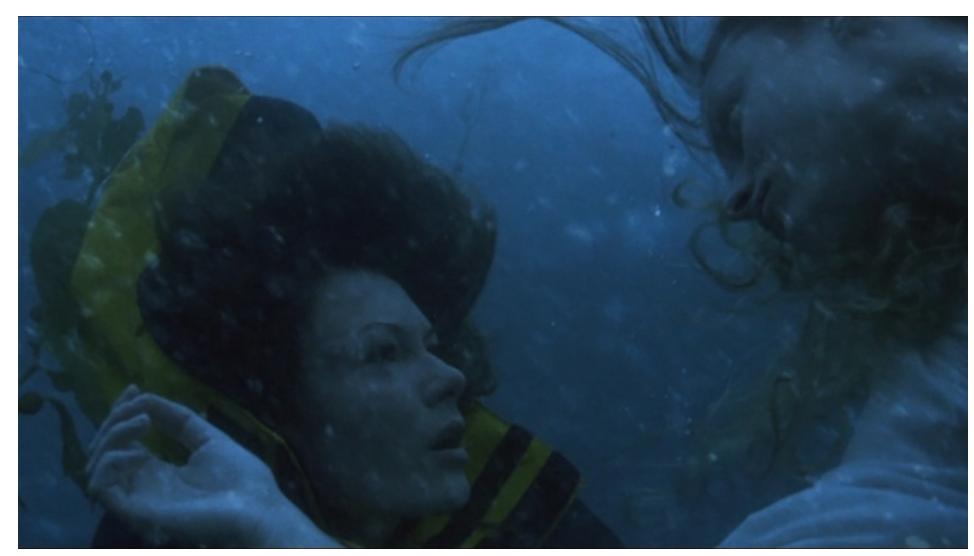

Fig. 6. Still from the film The Weight of Water, Kathryn Bigelow, Momentum Pictures, 2000. The past in the present: Jean face to face with Anethe. 
It records Jean finally perceiving the memories in feelings which have been, up until this point, if not unnoticed then ignored by her. ${ }^{6}{ }^{6}$ She has moved to an analytic understanding. This shift, an acknowledgment of the way past and present are linked rather than separable, the past bringing the presentness of the present into question, is initially registered acoustically through a speech that begins in the nineteenth century in the kitchen of the Hontvet house immediately after Maren has killed her sister. Maren's voice then carries across into the next shot of the storm in the present where it is then replaced by Jean who finishes the speech:

No one can say with any certainty unless he has lived through such an experience how he will react when rage overtakes the body and the mind / the anger is so swift and so piercing an attack before the senses like a bite on the hand.

Jean has now felt this rage, this anger. She has been unable to contain it and has let memories in feelings overwhelm her.

The scene in which the past is made visible in the present, in which Anethe and Maren appear alongside Jean, brings home how our memories of early infancy, our memories in feelings, our past, is still with us here in the now. The past is not to be confused with the historical re-enactment present in the film as period mise-enscene but is instead preserved and communicated at a sub-narrative level through the film's aesthetics. The Weight of Water provides more than a simple narrative reenactment. Its aesthetics grants the audience a means of accessing the psychic anxieties that underpinned the murders through investing their own feelings in the filmic experience. It can therefore be understood to operate on two levels, providing a sense of the inferred historical past and reviving the memories in feelings that precipitated the murders.

In the film, these memories in feelings are ones of anxiety and envy. Envy is defined by Klein as "the angry feeling that another person possesses and enjoys something desirable-the envious impulse being to take it away or spoil it."62 This explanation of envy characterizes Maren's relationship with Anethe-she is jealous (jealousy is understood by Klein to be an extension of envy, envy, like aggression and hate, as an extension of the death instinct) of Anethe's relationship with Ivan. It also

${ }^{6}$ It is noteworthy that this emergence of memories in feelings, which would be associated with the paranoid-schizoid position in Kleinian terms, occurs underwater. Gilles Deleuze links the paranoid-schizoid position with depth in The Logic of Sensation, where he writes that "[o]rality, mouth and breast are initially bottomless depths," in Gilles Deleuze, The Logic of Sensation, Constantin Boundas (tr.), London, Athlone Press, 1990, p. I87.

${ }^{62}$ Klein, "Envy and Gratitude," 1997, p. I8I. 
typifies Jean's resentment of Adaline because of her rapport with Thomas. That Jean and Maren are united in envy is reinforced by the speech they share in which rage is described as "like a bite on the hand." Klein suggests that the saying "to bite the hand which feeds one," which is readily associated with Jean's and Maren's simile, "is almost synonymous with biting, destroying, and spoiling the breast." ${ }_{63}$ Jean and Maren are both presented as unable to assimilate the good breast and thus possess increased aggressive, destructive impulses. ${ }^{64}$

Although in fact Maren did not commit the murders, this inaccuracy in The Weight of Water only exists at the level of the narrative, the anecdotal. The felt memory of the murders as re-enacted through the film is faithful to the past. There are dimensions of the Smuttynose murders that indicate that they be understood as a kind of restaging of events from early psychic life. Ronald Doctor advises that violent acts can form a means by which individuals communicate stories representing phantasies derived from early infancy. ${ }^{65}$ Louis Wagner, for instance, appears to have been driven by envy, an envy identified as directed at the financial security possessed by the Hontvets. In his description of Wagner, Edmund Pearson suggests: "to him, his poverty, his torn shoes, his want of the comforts of life were cosmic tragedies; compared with these, the slaughter of two or three innocent women, and the heartrending grief of two men, were of no consequence whatever. He was a simple savage; with a child's cruelty, a child's selfishness, a child's readiness to burst into tears." 66 Pearson is speculating and the precise motivations for Wagner's envy must remain uncertain but the murderous rage it led to is undeniable. ${ }^{67}$

Conflicting impulses of envy and gratitude, hate and love, are demonstrated by seemingly incompatible elements of the actual crime scene. Wagner, for example, struck Karen with the axe numerous times, far more than were necessary to kill her. Lyman Rutledge writes: "something in his sub-conscious fevered brain [seemed] to be vindicating itself, killing ten times over for the fiendish joy of killing." "68 Two women were brutally murdered but only one, Anethe, was found with a "garment

${ }^{6}$ Ibid., p. 182.

${ }^{64}$ For Klein, children endow parts of their parent's bodies with emotional life and meaning. The mother's breast, for example, is sometimes conceived as a source of love and goodness. See Julia Segal, Melanie Klein, London, Sage, I992, p. 38.

6s Doctor, 2008, p. 8I.

66 Pearson, 1926, p. 38.

${ }^{67}$ Rationalizations such as Pearson's can be interpreted as efforts to "contain" the crime by way of acts of explanation.

${ }^{68}$ Rutledge, 1958, p. 16. 
over her to cover the shocking wounds in the head and the pitiable nakedness of the body." ${ }^{6}$ This guilty gesture, interpreted as an act of tenderness in response to his destructiveness, of reparation, shows the divided nature of Wagner's emotions as he acted out past psychic conflict in the present. The film's narrative, by contrast, works through this conflict, which is displaced onto Maren and transferred to Jean.

\section{A Memorable Murder}

Jean is able to construct an accurate emotional understanding of the events of March 5, I873 by opening herself to the feelings underpinning what occurred, through introjecting Maren's emotions and re-enacting them. Her insights emerge from out of the memories in feelings she gleans from surviving accounts of the event including descriptions of the crime scene. As previously discussed, the film figures these memories in feelings for the spectator through emotional and graphic matches, and through studied depictions of the sea as split, capturing its sometimes tranquil, sometimes violent aspects.

The sea performs a similar function in Thaxter's "A Memorable Murder." Thaxter's impressionistic prose, like the film's visual poetics, similarly carries the feel of historical events to the reader. Her tightly crafted essay is edged by the inchoate, by memories in feelings, which her language strives to contain and express. This raw, unformed feeling is gestured towards through repeated references to uncertain visual (and occasionally acoustic) phenomena. In the description of Wagner's journey to Smuttynose, for example, the islands he passes are "full of chilly gleams and glooms" and the sea is "full of vague sounds, of half lights and shadows." 70

It is this repeated use of imagery referencing a loss of visual clarity, of outline, that provides the writing with what could be called a painterly aspect. For Heinrich Wölfflin, linear and painterly approaches to painting embody two differing conceptions of the world formed, respectively, of lines and masses. Wölfflin equates the painterly with a desire to capture the "shifting semblance" of things as they are perceived, with subjective experience, whereas linear artworks strive to depict things objectively. ${ }^{71}$ Painterly representations grant patches of light and colour a measure of independence from form. Thaxter's prose manifests a heightened attentiveness to these visual phenomena. This may be linked to her interest in watercolour: she

\footnotetext{
69 Pearson, 1926, p. 30.

70 Thaxter, 1875, p. 608.

${ }^{71}$ Heinrich Wölfflin, Principles of Art History, Mineola, New York, Dover, 1950, p. I4.
} 
produced several watercolours of the Shoals in the 1870 and 1880 os..$^{72}$ Wölfflin perceives the painterly, from whatever period of the history of art, as standing on "impressionist ground." 73 The Impressionist movement, with its intense amplification of the painterly, provides its ultimate formulation. Thaxter was friends with American Impressionist painters, particularly Childe Hassam, who produced illustrations for her later work, An Island Garden (1894). ${ }^{74}$ Hassam's works demonstrate a similar sensibility to Thaxter's regarding the shifting appearances of sea and sky in the Shoals.75 Thaxter's prose, however, manifested impressionistic qualities prior to their friendship.

In "A Memorable Murder," Wagner is described as a creature of the shadows, a man who is "always lurking in corners." ${ }^{6}$ To lurk, when used figuratively, means to escape observation, to be out of sight. He is also referred to as a "nameless, formless terror." 77 Thaxter's language here is reminiscent of Bion's later reference to the infant's "nameless dread," which requires containing. ${ }^{8}$ There is something about Wagner in Thaxter's prose construction of him that resists being apprehended and put into words. We might understand Thaxter's Wagner as linked with feelings from the pre-verbal stage of infant psychic development. His nearest counterpart in Thaxter's other prose is the garden slug as it is described in An Island Garden: "He is beyond description, repulsive, a mass of sooty, shapeless slime, and he devours everything."79 The Smuttynose murders may have been on Thaxter's mind when writing this passage, in which case the garden becomes the setting for her unconscious re-enactment of the crime. Two pages earlier Thaxter writes of "the Norwegians having a pretty and significant word 'Opelske,' which they use in speaking of the care

${ }^{72}$ For a discussion of Thaxter as visual artist, see Sharon Paiva Stephan, One Woman's Work: The Visual Art of Celia Laighton Thaxter, Portsmouth, New Hampshire, Peter Randall, 2ooI.

73 Wölfflin, 1950, p. 22.

74 Thaxter, An Island Garden, Boston, Houghton Mifflin, I894.

75 For an overview of Hassam's paintings of the Shoals, see the exhibition catalogue edited by Austen Bailly and John Coffey, American Impressionist: Childe Hassam and the Isles of Shoals, New Haven, Connecticut, Yale University Press, 2016.

${ }^{76}$ Thaxter, 1875 , p. 604.

77 Ibid., p. 609.

${ }^{78}$ Bion, 1962 , p. 96.

79 Thaxter, I894, p. 7. 
of flowers." "\$o It is possible that Karen, who had worked as a servant for Thaxter's family, taught her this word. ${ }^{81}$ In An Island Garden, flowers are therefore, perhaps, briefly employed as a metaphor for Karen and "the loathsome slug, a slimy, shapeless creature that devours every fair and exquisite thing" is used to embody Wagner and the feelings Thaxter associates him with. ${ }^{82}$

At the end of "A Memorable Murder," Thaxter portrays Smuttynose as haunted by Wagner and his victims; she details a vision of "two dim, reproachful shades who watch while an agonized ghost prowls eternally about the dilapidated houses at the beach's edge, close by the black, whispering water." ${ }^{3} 3$ The chromatics at work here contribute to the emotive power of the passage, tinging the description of the murders with negative feeling. Wagner is linked with the black sea. This echoes an earlier description of the murderer as a "black atom creeping over the face of the planet with [...] colossal evil in his heart" ${ }^{\prime 4}$ (see Fig. 7). He is also referred to as having a "heart full of darkness, blacker than the black tide that swirled beneath his boat." "s Through an exploitation of colour, Thaxter invites her readers to identify with the sea, to match their feelings to it, and therefore with the feelings related to Wagner's black character. The sea performs a key role here; it seems stained with Wagner's emotional state.

The conflicting impulses that Thaxter believes characterized Wagner are also present in her portrayal of the sea. It is not always cold and black like the envious murderer. It also has a gentle side: "the vast dim ocean whispers with a thousand waves; against the boat's side the ripples lightly tap, and pass and are lost; the air is full of fine, mysterious voices of winds and waters." ${ }^{86}$ Here the sea is mild and softly spoken. This echoes an earlier description of waves that "whispered gently" about

8o Ibid., p. 5. Thaxter is referring to opp elske, which translates literally as "up love" but means "nurture." If Karen is on her mind at this moment, then she is associated with nurturing, with the maternal.

${ }^{81}$ For a discussion of Thaxter's relationship to Karen and to the Norwegian community of the Shoals more broadly, see Einar Haugen, "Celia Thaxter and the Norwegians of the Isles of Shoals," in Faith Ingwersen and Mary Norseng (eds.), Fin(s) de Siècle in Scandinavian Perspective, Columbia, South Carolina, Camden House, 1993, p. 170-178.

${ }^{82}$ Thaxter, 1894, p. 6.

83 Thaxter, i875, p. 615.

${ }^{8}$ Ibid., p. 608.

85 Ibid., p. 607.

${ }^{86}$ Ibid., p. 608. 
bell as he rowed by, though a danger more subtle, more deadly, than fog, or hurricane, or pelting storm was passing swift beneath it. Unchallenged by anything in earth or heaven, he kept on his way and gained the great outer ocean, doubtless pulling strong and steadily, for he had no time to lose, and the longest night was all too short for an undertaking such as this. Nine miles from the light-houses to the islands! Slowly he makes his way; it seems to take an eternity of time. And now he is midway between the islands and the coast. That little toy of a boat with its one occupant in the midst of the awful, black, heaving sea! The vast dim ocean whispers with a thousand waves; against the boat's side the ripples lightly tap, and pass and are lost; the air is full of fine, mysterious voices of winds and waters. Has he no fear, alone there on the midnight sea with such a purpose in his heart? The moonlight sends a long, golden track across the waves; it touches his dark face and figure, it glitters on his dripping oars. On his right hand Boone Island light shows like a setting star on the horizon, low on his left the two beacons twinkle off Newburyport, at the mouth of the Merrimack River; all the light-houses stand watching along the coast, wheeling their long, slender shafts of radiance as if pointing at this black atom creeping over the face of the planet with such colossal evil in his heart. Before him glitters the Shoals' light at White Island, and helps to guide him to his prey. Alas, my friendly light-house, that you should serve so terrible a purpose! Steadily the oars click in the rowlocks; stroke after stroke of the broad blades draws him away from the lessening line of land, over the wavering floor of the ocean, nearer the lonely rocks. Slowly the coast - lights fade, and now the rote of the sea among the lonely ledges of the Shoals salutes his attentive ear. A little longer and he nears Appledore, the first island, and now he passes by the snow-covered, ice-bound rock, with the long buildings showing clear in the moonlight. He must have looked at them as he went past. I wonder we who slept beneath the roofs that glimmered to his eyes in the uncertain light did not feel, through the thick veil of sleep, what fearful thing passed by ! But we slumbered peacefully as the unhappy women whose doom every click of those oars in the rowlocks, like the ticking of some dreadful clock, was bringing nearer and nearer. Between the islands he passes; they are full of chilly gleams and glooms. There is no scene more weird than these snow-covered rocks in winter, more shudderful and strange: the moonlight touching them with mystic glimmer, the black water breaking about them and the vast shadowy spaces of the sea stretching to the horizon on every side, full of vague sounds, of half lights and shadows, of fear, and of mystery. The island he seeks lies before him, lone and still; there is no gleam in any window, there is no help near, nothing upon which the women can call for succor. He does not land in the cove where all boats put in, he rows round to the south side and draws his boat up on the rocks. His red returning footsteps are found here next day, staining the snow. He makes his way to the house he knows so well.

All is silent: nothing moves, nothing sounds but the hushed voices of the sea. His hand is on the latch, he enters stealthily, there is nothing to resist him. The little dog, Ringe, begins to bark sharp and loud, and Karen rouses, crying, " John, is that you?" thinking the expected fishermen had returned. Louis seizes a chair and strikes at her in the dark; the clock on a shelf above her head falls down with the jarring of the blow, and stops at exactly seven minutes to one. Maren in the next room, waked suddenly from her sound sleep, trying in vain to make out the meaning of it all, cries, "What's the matter?" Karen answers, "John scared me!" Maren springs from her bed and tries to open her chamber door; Louis has fastened it on the other side by pushing a stick through over the latch. With her heart leaping with terror the poor child shakes the door with all her might, in vain. Utterly confounded and bewildered, she

Fig. 7. Page from Celia Thaxter's “A Memorable Murder," Atlantic Montbly, no. 35, I875. Image courtesy of Google. 
Smuttynose. ${ }^{87}$ Thaxter's seascape, like the sea in The Weight of Water, is used to capture envy and gratitude, anger and tenderness, the twin feelings that form the emotional history that was behind the murders. The sea functions like the maternal breast into which Klein believes the infant initially projects contrasting feelings of hate and love. Descriptions of the sea provide a container for the reader's feelings, a means by which they can re-enact experiences from early psychic life such as splitting. Comparable passages that invite reviving past psychic processes in the present can be found in Thaxter's 1873 work Among the Isles of Shoals. ${ }^{88}$ The difference in "A Memorable Murder" is that the composition is also dedicated to describing a violent form of re-enactment that is similarly psychically motivated. This gives the memories in feelings as they appear in "A Memorable Murder" a narrative framework possessing explanatory potential that is absent in earlier writings.

\section{CONCLUSION: ONCE MORE, WITH FEELING...}

In The Weight of Water, colour, gesture, rhythm, and sound combine to cultivate memories in feelings and render the past alive in the present. Thaxter's prose employs comparable practices, namely a cultivated visual uncertainty and a particularly dark palette, to bring the alive past to the fore. Both film and essay enable the past in the present to be registered-the film through its visual poetics, Thaxter's prose through its impressionistic aspect, its painterliness. The kinds of re-enactment the film and the essay invite involve some of the psychic processes that can accompany transference such as projective identification.

The memories in feelings that the texts realize are not verbalized and the texts therefore assume a role in some ways akin to that of the mother receiving the bad feelings of the infant or of the analyst receiving wordless communications. The fear and anxiety, the aggression and tenderness, the hate and love the texts contain derive from the reader or spectator but appear to them as if derived from the essay or the film. As containers, essay and film enable a degree of integration of the memories in feelings, which the reader or spectator transfers to them. The narrative combines with the memories in feelings as they are revived in the sub-narrative, containing them, and relays a kind of interpretation to the reader or spectator. Through this interpretation, those open to memories in feelings gain insight into the psychic conflicts, the emotional pasts that underlie the actions of historical protagonists such as Wagner at

87 Ibid., p. 606.

${ }^{88}$ Thaxter, Among the Isles of Shoals, Boston, James Osgood, I873. 
Smuttynose. Simultaneously, they also gain awareness of their own memories in feelings, of their own good and bad aspects, their own envies and affections. Through this awareness, this enhanced understanding (an understanding derived from how the texts combine re-enactment and interpretation), a potential for working through emerges, a way of finding feelings anew. 


\title{
Once More, with Feeling: Re-investigating the Smuttynose Island Murders
}

\author{
Nicholas Chare, Université de Montréal
}

\section{ABSTRACT}

During the night of March 5, I873, two Norwegian women were murdered on Smuttynose Island in the Isles of Shoals off the New Hampshire coast. The crime has attracted significant and enduring attention. This article examines two depictions of the murders-Celia Thaxter's i875 essay “A Memorable Murder” and Kathryn Bigelow's film from 2000 The Weight of Water, an adaptation of Anita Shreve's novel of the same name. Employing psychoanalytic thinking inspired by the theories of Melanie Klein and Ruth Riesenberg-Malcolm, I examine how these literary and filmic re-enactments facilitate the reviving of the past in the present and how they foster an experience akin to transference as it is conceived in the analytic situation.

\section{RÉSUMÉ}

Dans la nuit du 5 mars 1873, deux Norvégiennes ont été assassinées sur l'île de Smuttynose, dans les îles de Shoals, à deux pas de la côte du New Hampshire. Le crime a attiré et continue d'attirer beaucoup d'attention. Cet article s'intéresse à deux représentations des meurtres: un essai de Celia Thaxter datant de 1875, «A Memorable Murder », et le film The Weight of Water (Kathryn Bigelow, 200o), une adaptation du roman du même titre publié par Anita Shreve en 1997. En recourant à la pensée psychanalytique inspirée par Melanie Klein, j'analyse comment ces reconstitutions littéraire et filmique facilitent la relance du passé dans le présent. À l'aide de l'article de Ruth Riesenberg-Malcolm intitulé « Interpretation: the Past in the Present », j'examine comment l'essai et le film favorisent une expérience analogue au transfert, tel qu'il est conçu dans la situation analytique.

\section{NOTE BIOGRAPHIQUE}

Nicholas Chare is Associate Professor of Modern Art in the Department of History of Art and Film Studies at the Université de Montréal. He is the author of Sportswomen in Cinema: Film and the Frailty Myth (2015), the co-author (with Dominic Williams) of Matters of Testimony: Interpreting the Scrolls of Auschwitz (2016) and the co-editor (with Liz Watkins) of the volume Gesture and Film: Signalling New Critical Perspectives (2017). He is also an editor of the journal $R A C A R$. 